\title{
INDEX To Volume 32 (2014)
}

\section{ARTICLES}

BOHLING, Joseph. The Mendès France Milk Regime: Alcoholism as a Problem of Agricultural Subsidies, 1954-1955 (Vol. 32, No. 3, 97)

DE LUCA, Marino. Les électeurs socialistes dans les primaires présidentielles à Paris (Vol. 32, No. 2, 123)

REID, Donald. Larzac in the Broad 1968 and After (Vol. 32, No. 2, 99)

SCHECK, Raffael. Léopold Sédar Senghor prisonnier de guerre allemand: Une nouvelle approche fondée sur un texte inédit (Vol. 32, No. 2, 76)

SHURTS, Sarah. Continental Collaboration: The Transition from Ultranationalism to Pan-Europeanism by the Interwar French Fascist Right (Vol. 32, No. 3, 79)

TOLOUDIS, Nicholas. The Carnot Commission and the Teacher Insurgency of Second Republic France (Vol. 32, No. 3, 57)

WATERS, Sarah. A Capitalism That Kills: Workplace Suicides at France Télécom (Vol. 32 , No. 3,121$)$

\section{SPECIAL ISSUE ON REPRESENTATIONS, HISTORY, AND WARTIME FRANCE}

BOWLES, Brett. Introduction (Vol. 32, No. 1, 1)

BOWLES, Brett. Résistance oblige? Historiography, Memory, and the Evolution of Le Silence de la mer, 1942-2012 (Vol. 32, No. 1, 68)

BRACHER, Nathan. Hélène Berr et l'écriture de l'histoire (Vol. 32, No. 1, 4)

MOURE, Kenneth. Black Market Fictions: Au bon beurre, La traversée de Paris, and the Black Market in France (Vol. 32, No. 1, 47)

OTT, Sandra. Undesirable Pen Pals, Unthinkable Houseguests: Representations of Franco-German Friendships in a Post-Liberation Trial Dossier and Suite Française (Vol. 32, No. 1, 26)

\section{SPECIAL ISSUE ON FRENCH STUDIES AND ITS FUTURES}

CHAPMAN, Herrick. Introduction: Flourishing in a Tough Climate (Vol. 32, No. 2, 1) DUBOIS, Laurent and MBEMBE, Achille. Nous sommes tous francophones (Vol. 32, No. 2, 40) 
FRADER, Laura. French History: Old Paradigms, Current Tendencies, New Directions (Vol. 32, No. 2, 21)

GOLDHAMMER, Arthur. A Few Thoughts on the Future of French Studies (Vol. 32, No. 2, 15)

LAMONT, Michèle and DEVOUX, Nicolas. How Neo-Liberalism Has Transformed France's Symbolic Boundaries? (Vol. 32, No. 2, 57)

ROSS, George. Can French Studies Exist Today? (Vol. 32, No. 2, 9)

SAADA, Emmanuelle. More than a Turn? The "Colonial" in French Studies (Vol. 32, No. 2, 34)

THERENTY, Marie-Ève. La civilisation du journal entre histoire et littérature: Perspectives et prospectives (Vol. 32, No. 2, 49)

\section{DOSSIER ON TECHNOLOGY, THE VISUAL, AND CULTURE}

COHEN, Margaret. Underwater Optics as Symbolic Form (Vol. 32, No. 3, 1)

RUDOLPH, Nicole C. "Plunging the Soul into Contemplation": On MoMA's Le Corbusier: An Atlas of Modern Landscape (Vol. 32, No. 3, 45)

SCHWARTZ, Vanessa R. Dimanche à Orly: The Jet-Age Airport and The Spectacle of Technology Between Sky and Earth (Vol. 32, No. 3, 24)

\section{REFLECTIONS, EVENTS, AND DEBATES}

MEHLMAN, Jeffrey. The Joinovici Affair: The Stavisky of the Fourth Republic (Vol. 32, No. 1, 101)

\section{REVIEW ESSAYS}

CRAIUTU, Aurelian. In Rousseau's Shadow (Vol. 32, No. 2, 143)

JOUAN-WESTLUND, Annie. Ça commence aujourd'hui, Etre et avoir et Entre les murs: Une vision diffractée de l'école républicaine française (Vol. 32, No. 1, 111)

\section{BOOK REVIEWS}

BERNARD, Claudie. La Virginité féminine: Mythes, fantasmes, émancipation by Yvonne Knibiehler (Vol. 32, No. 1, 130)

BOITTIN, Jennifer Anne. French Primitivism and the Ends of Empire, 1945-1975 by Daniel J. Sherman (Vol. 32, No. 2, 159)

COFFIN, Judith G. The Law of Kinship: Anthropology, Psychoanalysis, and the Family in France by Camille Robcis (Vol. 32, No. 3, 147)

CURTIS, Sarah A. The Pariahs of Yesterday: Breton Migrants in Paris by Leslie Page Moch (Vol. 32, No. 1, 127)

DOUGHTY, Robert. Verdun: The Longest Battle of the Great War by Paul Jankowski (Vol. 32, No. 3, 142)

ENDY, Christopher. The French Way: How France Embraced and Rejected American Values and Power by Richard F. Kuisel (Vol. 32, No. 1, 137) 
FOGG, Shannon L. France under Fire: German Invasion, Civilian Flight, and Family Survival during World War II by Nicole Dombrowski Risser (Vol. 32, No. 2, 153)

GORDON, Bertram M. Exclusions: Practicing Prejudice in French Law and Medicine, 1920-1945 by Julie Fette (Vol. 32, No. 1, 133)

KARLSGODT, Elizabeth Campbell. Divided Memory: French Recollections of World War II from the Liberation to the Present by Olivier Wieviorka (Vol. 32, No. 2, 155)

REID, Donald. Dreaming in French: The Paris Years of Jacqueline Bouvier Kennedy, Susan Sontag, and Angela Davis by Alice Kaplan (Vol. 32, No. 3, 145)

SEIDMAN, Michael. La Fin du village: Une histoire française by Jean-Pierre Le Goff (Vol. 32, No. 1, 140)

SMITH, Andrea. Rites of the Republic: Citizens' Theatre and the Politics of Culture in Southern France by Mark Ingram (Vol. 32, No. 1, 143)

WAKEMAN, Rosemary. Paris Dreams, Paris Memories: The City and Its Mystique by Charles Rearick (Vol. 32, No. 2, 151)

\section{INDEX OF BOOKS REVIEWED}

DOMBROWSKI RISSER, Nicole. France under Fire: German Invasion, Civilian Flight, and Family Survival during World War II reviewed by Shannon L. Fogg (Vol. 32, No. 2, 153)

FETTE, Julie. Exclusions: Practicing Prejudice in French Law and Medicine, 1920-1945 by Bertram M. Gordon (Vol. 32, No. 1, 133)

INGRAM, Mark. Rites of the Republic: Citizens' Theatre and the Politics of Culture in Southern France reviewed by Andrea Smith (Vol. 32, No. 1, 143)

JANKOWSKI, Paul. Verdun: The Longest Battle of the Great War reviewed by Robert Doughty (Vol. 32, No. 3, 142)

KAPLAN, Alice. Dreaming in French: The Paris Years of Jacqueline Bouvier Kennedy, Susan Sontag, and Angela Davis reviewed by Donald Reid (Vol. 32, No. 3, 145)

KNIBIEHLER, Yvonne. La Virginité féminine: Mythes, fantasmes, émancipation reviewed by Claudie Bernard (Vol. 32, No. 1, 130)

KUISEL, Richard F. The French Way: How France Embraced and Rejected American Values and Power reviewed by Christopher Endy (Vol. 32, No. 1, 137)

LE GOFF, Jean-Pierre. La Fin du village: Une histoire française reviewed by Michael Seidman (Vol. 32, No. 1, 140)

PAGE MOCH, Leslie. The Pariahs of Yesterday: Breton Migrants in Paris reviewed by Sarah A. Curtis (Vol. 32, No. 1, 127)

REARICK, Charles. Paris Dreams, Paris Memories: The City and Its Mystique reviewed by Rosemary Wakeman (Vol. 32, No. 2, 151)

ROBCIS, Camille. The Law of Kinship: Anthropology, Psychoanalysis, and the Family in France reviewed by Judith G. Coffin (Vol. 32, No. 3, 147)

SHERMAN, Daniel J. French Primitivism and the Ends of Empire, 1945-1975 reviewed by Jennifer Anne Boittin (Vol. 32, No. 2, 159)

WIEVIORKA, Olivier. Divided Memory: French Recollections of World War II from the Liberation to the Present reviewed by Elizabeth Campbell Karlsgodt (Vol. 32, No. 2, 155) 